\title{
Use of residential wood heating in a context of climate change: a population survey in Québec (Canada) Diane Bélanger ${ }^{1}$, Pierre Gosselin*2, Pierre Valois ${ }^{3}$ and Belkacem Abdous ${ }^{4}$
}

\begin{abstract}
Address: ${ }^{1}$ Institut national de santé publique du Québec and Centre de recherche du CHUQ, 945 Avenue Wolfe, Québec (Québec), G1V 5B3, Canada , ${ }^{2}$ Institut national de santé publique du Québec, Ouranos and Université Laval, 945 Avenue Wolfe, Québec (Québec), G1V 5B3, Canada

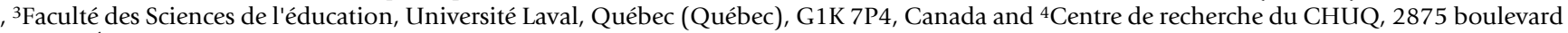
Laurier, Édifice Delta 2, Québec (Québec), G1V 2M2, Canada
\end{abstract}

Email: Diane Bélanger - diane.belanger@crchul.ulaval.ca; Pierre Gosselin* - pierre-l.gosselin@crchul.ulaval.ca;

Pierre Valois - pierre.valois@fse.ulaval.ca; Belkacem Abdous - belkacem.abdous@crchul.ulaval.ca

* Corresponding author

Published: 28 May 2008

BMC Public Health 2008, 8:184 doi:10.1 |86/147|-2458-8-184
Received: 4 January 2008

Accepted: 28 May 2008

This article is available from: http://www.biomedcentral.com/I47|-2458/8//84

(C) 2008 Bélanger et al; licensee BioMed Central Ltd.

This is an Open Access article distributed under the terms of the Creative Commons Attribution License (http://creativecommons.org/licenses/by/2.0), which permits unrestricted use, distribution, and reproduction in any medium, provided the original work is properly cited.

\begin{abstract}
Background: Wood heating is recommended in several countries as a climate change (CC) adaptation measure, mainly to increase the autonomy of households during power outages due to extreme climatic events. The aim of this study was to examine various perceptions and individual characteristics associated with wood heating through a survey about CC adaptations.

Methods: A telephone survey $(n=2,545)$ of adults living in the southern part of the province of Québec (Canada) was conducted in the early fall season of 2005. The questionnaire used closed questions and measured the respondents' beliefs and current adaptations about CC. Calibration weighting was used to adjust the data analysis for the respondent's age and language under stratified sampling based on health regions.

Results: More than three out of four respondents had access to a single source of energy at home, which was mainly electricity; $22.2 \%$ combined two sources or more; $18.5 \%$ heated with wood occasionally or daily during the winter. The prevalence of wood heating was higher in the peripheral regions than in the more urban regions, where there was a higher proportion of respondents living in apartments. The prevalence was also higher with participants completely disagreeing (38.5\%) with the eventual prohibition of wood heating when there is smog in winter, compared to respondents somewhat disagreeing (24.2\%) or agreeing (somewhat: 17.5\%; completely: 10.4\%) with the adoption of this strategy. It appears that the perception of living in a region susceptible to winter smog, smog warnings in the media, or the belief in the human contribution to CC, did not influence significantly wood heating practices.

Conclusion: Increased residential wood heating could very well become a maladaptation to climate change, given its known consequences on winter smog and respiratory health. It would thus be appropriate to implement a long-term national program on improved and controlled residential wood heating. This would constitute a "no-regrets" adaptation to climate change, while reducing air pollution and its associated health impacts.
\end{abstract}




\section{Background}

In Canada, minimum and maximum temperatures have increased over the last few decades, particularly in winter [1]. For instance, in southern Québec (south of the 49th parallel) average temperatures have increased by $0.5^{\circ} \mathrm{C}$ to $1.2^{\circ} \mathrm{C}$ based on an east-west trajectory [2]. These increases however, do not mean that climate warming is linear [3]. In fact, periods of intense cooling and severe storms are still predicted to occur. People will have to adapt appropriately, if only to prevent the health impacts of concern due to the cold $[4,5]$.

A winter adaptation strategy is the use of residential wood heating. In Canada, more than 3 million dwellings use it as the primary or secondary source of heat [6]. Furthermore, the popularity of this type of heating grew in Québec to the point that its penetration rate increased by approximately 60\% between 1987 and 2000 while the number of dwellings increased by less than 20\% [7]. The massive and prolonged power outages that occurred in the middle of winter during the ice storm of 1998 [8] are thought to have played a significant role in this increase. In fact, the Web site of the Department of Natural Resources of Canada highlights this extreme climatic event in referring to evolved wood burning techniques as a means of coping with the worst winter storms [9].

Residential wood heating is also one of the main causes of winter smog in Canada. This type of heating is in fact responsible for $29 \%$ of Canadian emissions of fine particulates - one of the two key components of smog and its main winter component [10] from anthropogenic sources [11]. This relative contribution of fine particulates to emissions is even higher in Quebec at 47\% [12] compared to most jurisdictions using fossil fuels for power generation, because hydroelectricity accounts for $96 \%$ of electricity production in the province and a great many homes use electric heat as the main source of heating.

Moreover, among the approximately one hundred atmospheric pollutants in wood smoke, several are greenhouse gases, while others are precursors of tropospheric ozone the other key component of smog [13]. Furthermore, human exposure to fine particulates and tropospheric ozone is of particular concern because there are still no established concentration thresholds below which these pollutants are known to be safe and not pose a human health risk [13]. Young children, the elderly and people with respiratory problems (e.g., asthmatics) or heart problems are the most vulnerable, while healthy people who are repeatedly exposed, such as users of combustion units and their neighbours may also be at risk [7,14,15]. Finally, a well-known relationship exists between the harmful effects of these atmospheric pollutants and the increase in the number of visits to emergency rooms, hospitaliza- tions, health care costs, absenteeism, the reduction in the labour force participation rate, as well as premature death [16].

Clearly, the rise in popularity of residential wood heating is a public health concern [16]. And it will continue to grow should the supply and demand for this type of heating increase as extreme climatic events become more frequent and intense [1]. The aim of this study was to examine diverse perceptions and characteristics associated with wood heating through a survey carried out in 2005 in southern Québec, Canada [17] in the context of a research program aiming to propose climate change (CC) adaptation strategies that respect the environment as well as health and well-being.

\section{Methods \\ Population studied and sample}

The population studied consisted of adults aged 18 years or older, resident of the Province of Québec south of the 49th parallel, namely all the health regions presented in Figure 1, except for regions 10, 17 and 18.

The sample was stratified by the health region of residence, and post-stratified by gender (in order to take into account the greater difficulty in reaching men [18]) (Table 1). Due to operational and budgetary constraints, we used random household sampling rather than within-household sampling. The respondents were contacted by a polling firm from random digit dialing of published residential telephone numbers. Confidential numbers were not used for ethical considerations. The study obtained ethical approval from Laval University's Comité d'éthique de la recherche avec des êtres humains. The consent was implicit as only adults whose phone number was published were interviewed; Laval University's ethics committee does not request any formal consent for such phone surveys.

The sample was calculated using 2001 survey data [19], for a $95 \%$ confidence level and a precision level of $1.5 \%$, for a 4-point Likert-type scale including 6 items [20]. The total sample was 5,088 respondents: half of them were contacted in the spring of $2005(n=2,543)$ on heatrelated adaptation measures [21], and the other half during the following autumn $(\mathrm{n}=2,545)$ on cold-related adaptation measures [17]. The present article pertains to the autumn data collection, in which $70.2 \%$ of the eligible people $(\mathrm{n}=3,726)$ completed the questionnaire; $4.9 \%$ were not interviewed because data collection ended before the date of the appointment made with the polling firm; $6.6 \%$ could not be reached (e.g., answering machine); less than one percent $(n=7)$ did not complete the interview; and $18.2 \%$ refused to answer the study. The 


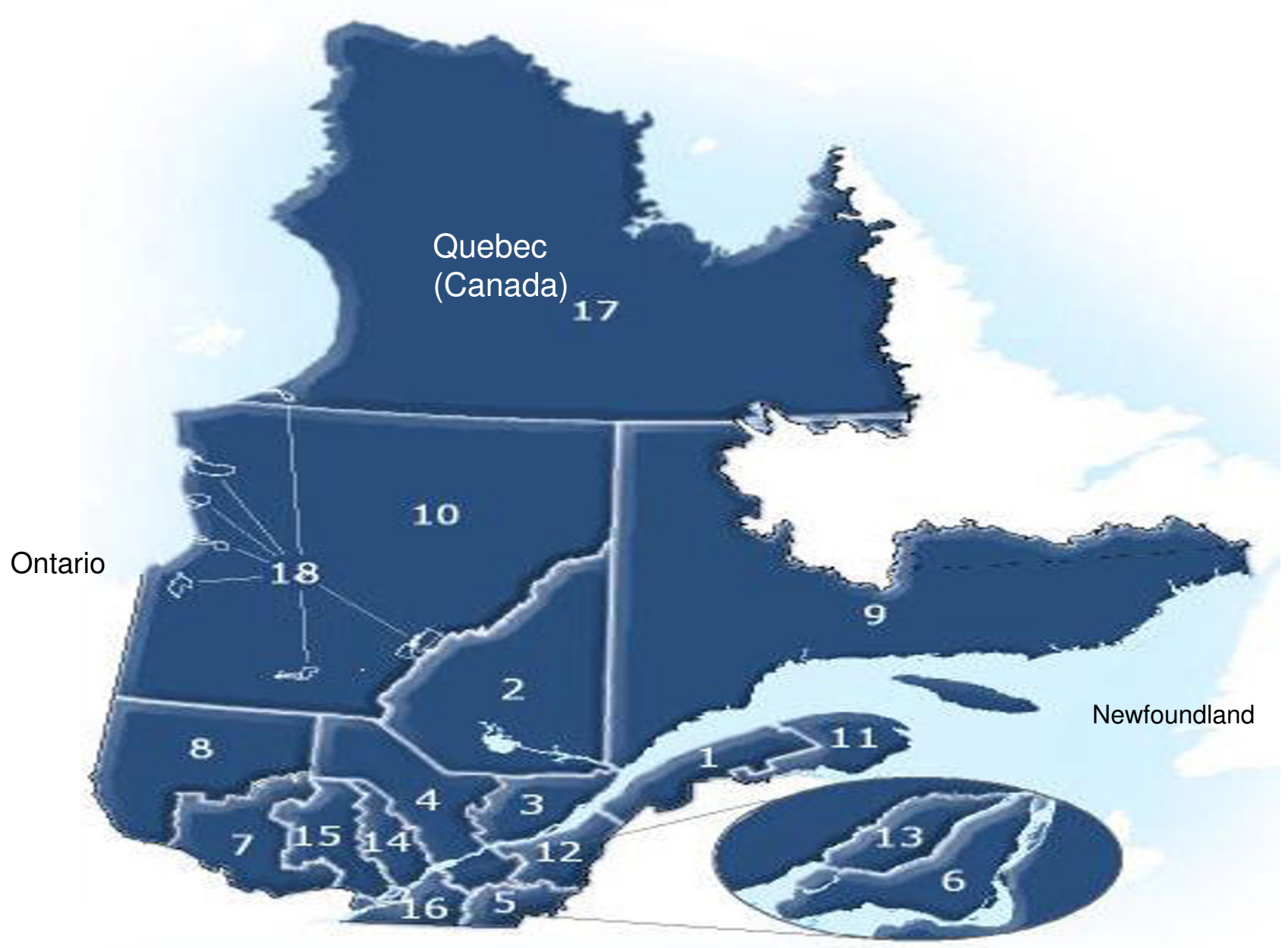

Figure I

Health regions of Québec (Canada). I : Bas-Saint-Laurent ; 2 : Saguenay-Lac-Saint-Jean ; 3 : Québec ; 4 : Mauricie-Centredu-Québec; 5 : Estrie; 6 : Montréal; 7 : Outaouais; 8 : Abitibi-Témiscamingue; 9 : Côte-Nord; II : Gaspésie-Îles-de-laMadeleine; 12 : Chaudière-Appalaches; 13 : Laval; I4 : Lanaudière; 15 : Laurentides; 16 : Montérégie. Source: MSSS, Service des Infocentres, 2006.

percentage of respondents and non-respondents were similar across health regions $(\mathrm{p}=0.4)$.

\section{Data collection method}

The polling firm collected individual responses by telephone (average duration: 20 minutes), seven days a week, from 9:30 a.m. to 9:30 p.m., using a computer system that allowed the order of the questions (essentially closed) to be randomly redistributed. More precisely, collection (from 15-09-2005 to 25-10-2005) allowed information to be gathered on behaviours adopted during a period of intense cold, socio-demographic characteristics, health status, dwelling, region of residence, the use of an auto- mobile and a remote starter during the winter, consultation of weather reports, as well as on various perceptions and beliefs relating to climate change.

The questionnaire was developed according to the following six steps: 1 /identifying the important issues to consider in the exploratory interviews [22] based on the literature on health and climate change; 2/conducting 21 face-to-face interviews (average duration: two hours), mainly to verify the understanding of some terms, identify the items to be retained as well as the sensitive issues to be excluded; 3/development of an initial version of the questionnaire; 4/conducting telephone interviews with 61 
Table I: Stratification process by data collection

\begin{tabular}{|c|c|c|c|c|c|c|c|}
\hline $\begin{array}{l}\text { Name of the health regions of } \\
\text { residence (number of the region) }\end{array}$ & Men $\geq 18$ years 1 & Proportion & Men: $n^{2}$ & Women $\geq 18$ years 1 & proportion & Women: $n^{2}$ & Men and women: $\mathrm{n}$ \\
\hline Bas-Saint-Laurent $(0 \mathrm{I})$ & 77455 & 0,014 & 36 & 82070 & 0,015 & 38 & 74 \\
\hline Saguenay-Lac-Saint-Jean (02) & 106700 & 0,019 & 48 & 110230 & 0,020 & 51 & 99 \\
\hline Capitale-Nationale (03) & 246320 & 0,044 & 112 & 271710 & 0,048 & 122 & 234 \\
\hline $\begin{array}{l}\text { Mauricie et Centre-du-Québec } \\
(04)\end{array}$ & 181185 & 0,032 & 81 & 193805 & 0,034 & 86 & 167 \\
\hline Estrie (05) & 107805 & 0,019 & 48 & 114940 & 0,020 & 51 & 99 \\
\hline Montréal (06) & 690890 & 0,122 & 310 & 775560 & 0,137 & 348 & 658 \\
\hline Outaouais (07) & 116260 & 0,021 & 53 & 124345 & 0,022 & 56 & 109 \\
\hline Abitibi-Témiscaminque (08) & 54720 & 0,010 & 25 & 55435 & 0,010 & 25 & 50 \\
\hline Côte-Nord (09) & 37710 & 0,007 & 18 & 36900 & 0,007 & 18 & 36 \\
\hline $\begin{array}{l}\text { Gaspésie-Îles-de-la-Madeleine } \\
\text { (II) }\end{array}$ & 37635 & 0,007 & 18 & 39550 & 0,007 & 18 & 36 \\
\hline Chaudière-Appalaches (12) & 146365 & 0,026 & 66 & 151090 & 0,027 & 69 & 135 \\
\hline Laval (I3) & 127755 & 0,023 & 58 & 138870 & 0,025 & 64 & 122 \\
\hline Lanaudière (14) & 144030 & 0,026 & 66 & 148550 & 0,026 & 66 & 132 \\
\hline Laurentides (15) & 171535 & 0,030 & 76 & 178430 & 0,032 & 81 & 157 \\
\hline Montérégie (16) & 474705 & 0,084 & 213 & 505235 & 0,090 & 229 & 442 \\
\hline TOTAL & $2,721,070$ & & 1228 & $2,926,720$ & & 1322 & 2550 \\
\hline
\end{tabular}

IInstitut de la statistique du Québec (20).

2Thompson (2I).

people aged 18 years or older (on average, four people per health region studied) to validate the clarity and precision of the questions, to comment on the questionnaire and to shorten it; 5/validation of the content of the questionnaire (French and English versions) by five experts working in the field of health and climate change in Canada; 6 / conducting a qualitative pretest $(n=50)$ (two versions of the questionnaire) by the polling firm, at the start of each data collection.

\section{Analyses}

The collected information was calibration weighted for the respondents' age and language, on the basis of 2001 census data [19]. Coefficients of variation (CV) were calculated (CV $\leq 15 \%$ : sufficiently precise estimates; CV between $15 \%$ and $25 \%$ : acceptable precision, estimates to be carefully interpreted; CV > 25\%: low precision, estimates to be interpreted with circumspection) [23]. The percentage totals for a given variable may not be exactly $100 \%$, due to rounding to the closest decimal (To simplify the presentation, percentages below $2 \%$ for missing data have not been reported). The analyses took into account the sample scheme stratified according to the health regions $[24,25]$. Wood heating was related to the independent variables using the Rao-Scott likelihood ratio chisquare test, which is a design-adjusted version of the Pearson chi-square test. The multivariate analyses were done using a logistic regression model with a stepwise method. The significance level required to be retained by the model: 0.2 ; to stay in the model: 0.1 ). The $\mathrm{c}$ index (area under the ROC curve; expected value $=0.5$ to 1.0 ) [26] was used as an indicator of the discriminant capacity of the final multivariate statistical model. Finally, the presence of collinearity between the independent variables was checked (VIF > 10; condition > 30) [27].

\section{Results}

\section{Characteristics of the respondents}

Women, as well as people 35 to 64 years of age accounted for slightly more than half of the sample (Table 2). At least two participants out of three lived in a house and spoke only French (Table 2), except in Montréal and Laval (Table 3).

More than three out of four respondents had access to a single source of energy at home, as follows: $60.8 \%$, electricity; $8.0 \%$, oil; $3.8 \%$, natural gas or propane; $3.7 \%$, firewood. The other participants (22.2\%) combined some of these sources (e.g., oil, gas, wood), with three out of five $(59.5 \%)$ combining electricity and wood.

\section{Factors associated with residential wood heating}

During the winter, $18.5 \%$ of the respondents heated with wood occasionally or daily and more precisely: $1.7 \%$, less than once a week; $4.5 \%$, a few days a week but not every day; and $11.9 \%$, every day.

Respondents with higher incomes used wood as a primary or secondary source of energy in a higher proportion than the other participants, as well as the respondents aged 
Table 2: Sociodemographic characteristics of the respondents: percentages corrected for stratified sampling and coefficients of variation

\begin{tabular}{|c|c|c|c|}
\hline \multicolumn{2}{|c|}{ Variables } & \multirow{2}{*}{$\begin{array}{c}\% 1 \\
51.6\end{array}$} & \multirow{2}{*}{$\begin{array}{l}\mathrm{CV}^{2} \\
0.02\end{array}$} \\
\hline Gender & Women & & \\
\hline & Men & 48.3 & 0.02 \\
\hline \multirow[t]{3}{*}{ Age } & 18 to 34 years & 29.1 & 0.03 \\
\hline & 35 to 64 years & 54.6 & 0.02 \\
\hline & 65 years or more & 16.2 & 0.05 \\
\hline \multirow[t]{4}{*}{ First language learned at home } & French only & 81.0 & 0.01 \\
\hline & English only & 6.1 & 0.09 \\
\hline & Language other than French or English & 10.1 & 0.15 \\
\hline & English or French plus another language & 2.9 & 0.08 \\
\hline \multirow[t]{4}{*}{ Status of activities (last I 2 months) } & Employed & 67.0 & 0.02 \\
\hline & Unemployed & 8.4 & 0.07 \\
\hline & Student & 3.4 & 0.15 \\
\hline & Retired & 21.8 & 0.04 \\
\hline \multirow[t]{6}{*}{ Income (before tax/from all sources/last 12 months) } & Less than $\$ 15000$ & 9.3 & 0.07 \\
\hline & Between \$ 15000 and \$ 29999 & 17.2 & 0.05 \\
\hline & Between $\$ 30000$ and $\$ 44999$ & 17.8 & 0.05 \\
\hline & Between $\$ 45000$ and \$ 59999 & 14.1 & 0.05 \\
\hline & $\$ 60000$ or more & 26.2 & 0.03 \\
\hline & Undisclosed 3 & 15.2 & 0.05 \\
\hline \multirow[t]{2}{*}{ Lives alone } & Yes & 18.2 & 0.04 \\
\hline & No & 81.8 & 0.01 \\
\hline \multirow[t]{7}{*}{ Region of residence } & Eastern Québec & 5.7 & 0.02 \\
\hline & Northern part of southern Québec & 5.9 & 0.02 \\
\hline & Québec City region & 14.6 & 0.01 \\
\hline & Centre of the province & 6.4 & 0.02 \\
\hline & South of Montréal & 21.1 & 0.01 \\
\hline & North of Montréal & 15.7 & 0.01 \\
\hline & Montréal and Laval & 30.8 & 0.01 \\
\hline \multirow[t]{3}{*}{ Type of dwelling } & House & 64.9 & 0.01 \\
\hline & Apartment: $\leq 4$ storeys & 31.1 & 0.03 \\
\hline & Apartment $>4$ storeys & 3.9 & 0.11 \\
\hline
\end{tabular}

\footnotetext{
1\%: percentages. The total percentages for a given variable may not be exactly $100 \%$, due to rounding to the closest decimal. To simplify the presentation, percentages below $2 \%$ for missing data have not been reported.

${ }^{2} \mathrm{CV}$, coefficients of variation. CV $\leq 15 \%$ : sufficiently precise estimates; CV between $15 \%$ and $25 \%$ : acceptable precision, estimates to be carefully interpreted; CV > 25\%: low precision, estimates to be interpreted with circumspection [25].

${ }^{3}$ These participants, compared to those who disclosed their income strata, were more often women, individuals at least 65 years of age, and retired people.
}

between 35 to 64 years, who spoke French only or in addition to another language, or who lived with children or with other people (Table 4).

Higher percentages of respondents heating with wood at least occasionally during the winter were observed for those individuals living a) in a house, b) in a dwelling built in 1983 or after, c) to which insulating materials had been added since its construction or in which the insulation efficiency was considered appropriate as protection against heat, cold and humidity (Table 4 ).

The prevalence of wood heating was higher in the peripheral regions than in the more urban regions located within the study area (Table 4), in particular in populated urban environments such as Montreal (Table 3). Similarly, higher percentages of respondents heating with wood at least occasionally during the winter were observed for those individuals who considered their region of residence to be at lesser risk of experiencing winter smog, or for those participants who believed in the contribution of anthropogenic causes to climate change in the last fifty years (Table 4).

The prevalence of residential wood heating was higher with participants who rarely or never consulted the smog warning in the media compared to those consulting more, or with participants who completely disagreed with the prohibition of wood heating during smog episodes in winter, as compared to respondents who somewhat disagreed, agreed somewhat, or completely with the adoption of this strategy (Table 4). 
Table 3: Some characteristics of the respondents by region of residence: percentages corrected for stratified sampling

\begin{tabular}{|c|c|c|c|c|c|c|c|}
\hline \multirow[b]{2}{*}{ Variables } & \multicolumn{7}{|c|}{ Region of residence } \\
\hline & $\begin{array}{l}\text { Eastern } \\
\text { Québec }\end{array}$ & $\begin{array}{l}\text { Northern } \\
\text { part of } \\
\text { southern } \\
\text { Québec }\end{array}$ & $\begin{array}{l}\text { Centre of } \\
\text { the province }\end{array}$ & $\begin{array}{l}\text { Québec City } \\
\text { region }\end{array}$ & $\begin{array}{l}\text { South of } \\
\text { Montréal }\end{array}$ & $\begin{array}{l}\text { North of } \\
\text { Montréal }\end{array}$ & $\begin{array}{l}\text { Montréal } \\
\text { and Laval }\end{array}$ \\
\hline \multicolumn{8}{|l|}{ Type of dwelling: } \\
\hline - House & $87.4 \% !$ & $78.8 \%$ & $76.0 \%$ & $67.2 \%$ & $73.8 \%$ & $85.0 \%$ & $38.4 \%$ \\
\hline - Apartment & $12.6 \%$ & $21.2 \%$ & $24.0 \%$ & $32.9 \%$ & $26.3 \%$ & $15.0 \%$ & $61.6 \%$ \\
\hline \multicolumn{8}{|c|}{ First language learned at home: } \\
\hline - French only & $96.0 \%$ & $95.0 \%$ & $96.2 \%$ & $93.4 \%$ & $86.1 \%$ & $85.3 \%$ & $60.8 \%$ \\
\hline - other than French only & $4.0 \%$ & $5.0 \%$ & $3.8 \%$ & $6.6 \%$ & $13.9 \%$ & $14.7 \%$ & $39.2 \%$ \\
\hline \multicolumn{8}{|c|}{$\begin{array}{l}\text { Region of residence perceived as } \\
\text { conducive to cold waves: }\end{array}$} \\
\hline - a lot & $27.0 \%$ & $41.5 \%$ & $23.3 \%$ & $31.9 \%$ & $34.6 \%$ & $33.9 \%$ & $41.1 \%$ \\
\hline - Average & $44.6 \%$ & $39.9 \%$ & $55.1 \%$ & $49.6 \%$ & $46.9 \%$ & $46.8 \%$ & $40.8 \%$ \\
\hline - not much & $19.3 \%$ & $17.1 \%$ & $16.0 \%$ & $16.0 \%$ & $15.4 \%$ & $15.0 \%$ & $14.1 \%$ \\
\hline - not at all & $9.2 \%$ & $1.6 \%$ & $5.6 \%$ & $2.5 \%$ & $3.2 \%$ & $4.3 \%$ & $4.0 \%$ \\
\hline \multicolumn{8}{|c|}{$\begin{array}{l}\text { Region of residence perceived as } \\
\text { conducive to winter smog: }\end{array}$} \\
\hline - a lot & $5.4 \%$ & $0.6 \%$ & $1.2 \%$ & $3.3 \%$ & $6.6 \%$ & $4.4 \%$ & $15.4 \%$ \\
\hline - Average & $12.4 \%$ & $8.8 \%$ & $19.2 \%$ & $17.2 \%$ & $22.5 \%$ & $20.3 \%$ & $31.5 \%$ \\
\hline - not much & $21.9 \%$ & $21.4 \%$ & $28.7 \%$ & $33.5 \%$ & $29.1 \%$ & $29.4 \%$ & $29.6 \%$ \\
\hline - not at all & $60.3 \%$ & $69.3 \%$ & $50.9 \%$ & $46.1 \%$ & $41.8 \%$ & $45.9 \%$ & $23.5 \%$ \\
\hline \multicolumn{8}{|l|}{ Wood heating: } \\
\hline - Yes & $35.0 \%$ & $34.8 \%$ & $30.7 \%$ & $23.0 \%$ & $21.9 \%$ & $24.9 \%$ & $4.0 \%$ \\
\hline - No & $65.0 \%$ & $65.2 \%$ & $69.3 \%$ & $77.0 \%$ & $78.1 \%$ & $75.2 \%$ & $96.0 \%$ \\
\hline \multicolumn{8}{|c|}{$\begin{array}{l}\text { Prohibition of wood heating when } \\
\text { there is winter smog: }\end{array}$} \\
\hline - completely agree & $26.2 \%$ & $33.8 \%$ & $29.8 \%$ & $27.5 \%$ & $36.1 \%$ & $37.3 \%$ & $48.5 \%$ \\
\hline - do not completely agree & $73.8 \%$ & $66.2 \%$ & $70.2 \%$ & $72.5 \%$ & $63.9 \%$ & $62.7 \%$ & $51.5 \%$ \\
\hline \multicolumn{8}{|c|}{$\begin{array}{l}\text { Belief of the contribution of } \\
\text { anthropogenic causes to climate } \\
\text { change in the last fifty years: }\end{array}$} \\
\hline - average or a lot & $79.3 \%$ & $76.9 \%$ & $82.8 \%$ & $78.0 \%$ & $85.2 \%$ & $85.0 \%$ & $84.1 \%$ \\
\hline - not much or not at all & $20.7 \%$ & $23.1 \%$ & $17.2 \%$ & $22.0 \%$ & $14.8 \%$ & $15.0 \%$ & $15.9 \%$ \\
\hline
\end{tabular}

IThe total percentages for a given variable may not be exactly $100 \%$, due to rounding to the closest decimal.

To simplify the presentation, percentages below $2 \%$ for missing data have not been reported.

In the multivariate analysis, ten of the variables associated with the use of residential wood heating seemed to differentiate occasional and daily users from non-users, and these are : (1) to live in a peripheral region; (2) to live in a house; (3) to not completely agree with the prohibition of wood heating when there is smog in winter; (4) to live in a dwelling built in 1983 or later, (5) to live in a dwelling to which insulating materials had been added since its construction, (6) or in which the insulation efficiency was considered appropriate as protection against warm conditions; (7) to consult smog warnings in the media; (8) to believe in the contribution of anthropogenic causes to climate change in the last fifty years; (9) to have income of at least 45000 \$; and (10) to have first learned at home, French only or in addition to another language. Among the $2^{10-1}$ (or 1023) sub-models, 64 models had a c index (area under the ROC curve; expected value $=0.5$ to 1.0 ) over 0.8 . The most discriminant model (c index: 0.8176 ) included nine of the preceding variables (except the addi- tion of insulating materials) and the most economic model, with a similar discriminant capacity (c index: 0.8029), had only the first three (Table 5).

More specifically (Table 5, models 1 and 2), compared to the respondents living outside the large urban regions of the province of Québec (e.g. regions 2 or 9, Figure 1), the odds of wood heating was 10 times lower for participants living in the cities of Montréal or Laval. The odds of wood use for heating was 10 times higher for residents of a house than respondents living in an apartment, a high proportion of whom lived in the regions of Montréal and Laval (Table 3). And compared to the respondents strongly hoping that wood heating would be prohibited during the presence of smog in winter, the odds of wood use for heating was 1.8 times higher for participants somewhat agreeing with this solution reported using this type of supplementary heating. This odds ratio was at least 2 for the participants somewhat disagreeing with this solu- 
Table 4: Use of residential wood heating in southern Québec for various respondents characteristics: percentages corrected for stratified sampling and $p$ value

\begin{tabular}{|c|c|c|c|}
\hline \multirow[b]{2}{*}{ Variables } & \multicolumn{2}{|c|}{ Wood heating } & \multirow[t]{2}{*}{$\mathrm{P}$ valuel } \\
\hline & yes & no & \\
\hline \multicolumn{4}{|l|}{ Sociodemographic characteristics } \\
\hline - Gender: & & & 0.1885 \\
\hline - men & $20.3 \% 2$ & $79,7 \%$ & \\
\hline - women & $18.2 \%$ & $81.8 \%$ & \\
\hline Age: & & & 0.0004 \\
\hline - 18-34 years & $16.2 \%$ & $83.8 \%$ & \\
\hline - 35-64 years & $22.4 \%$ & $77.6 \%$ & \\
\hline - 65 years or more & $14.5 \%$ & $85.5 \%$ & \\
\hline Status of activities (last 12 months): & & & 0.0374 \\
\hline • employed & $20.3 \%$ & $79.7 \%$ & \\
\hline - unemployed & $21.8 \%$ & $78.2 \%$ & \\
\hline - student & $11.6 \%$ & $88.4 \%$ & \\
\hline - retired & $15.7 \%$ & $84.3 \%$ & \\
\hline Income before tax, from all sources (last 12 months): & & & $<0.0001$ \\
\hline - $<\$ 45,000$ & $16.8 \%$ & $83.2 \%$ & \\
\hline$\cdot \geq \$ 45,000$ & $23.6 \%$ & $76.4 \%$ & \\
\hline - not disclosed & $14.4 \%$ & $85.6 \%$ & \\
\hline First language learned at home: & & & $<0.0001$ \\
\hline - French only & $21.9 \%$ & $78.2 \%$ & \\
\hline • English only & $4.9 \%$ & $95.1 \%$ & \\
\hline - other language in addition to French or English & $20.6 \%$ & $79.4 \%$ & \\
\hline - language other than French and English & $6.1 \%$ & $93.9 \%$ & \\
\hline Status as parent: & & & $<0.0001$ \\
\hline - no children & $14.7 \%$ & $85.3 \%$ & \\
\hline - adult children only & $20.0 \%$ & $80.0 \%$ & \\
\hline - at least one minor child & $23.2 \%$ & $76.8 \%$ & \\
\hline Cohabitation: & & & $<0.0001$ \\
\hline - lives with other people (related or not) & $21.0 \%$ & $79.0 \%$ & \\
\hline - lives alone & $11.9 \%$ & $88.1 \%$ & \\
\hline \multicolumn{4}{|l|}{ Health status } \\
\hline Perceived health status: & & & 0.1624 \\
\hline - very good & $20.1 \%$ & $79.9 \%$ & \\
\hline - good & $19.8 \%$ & $80.2 \%$ & \\
\hline - average & $15.6 \%$ & $84.4 \%$ & \\
\hline - bad & $12.8 \%$ & $87.2 \%$ & \\
\hline Having at least one chronic disease diagnosed by a physician and having had it for at least six months & & & 0.0809 \\
\hline - yes & $16.9 \%$ & $83.1 \%$ & \\
\hline - no & $20.0 \%$ & $80.0 \%$ & \\
\hline Observance of behaviours according to the preventive advice issued by health professionals & & & 0.5748 \\
\hline - always & $19.3 \%$ & $80.7 \%$ & \\
\hline - often & $18.3 \%$ & $81.7 \%$ & \\
\hline - sometimes & $21.8 \%$ & $78.2 \%$ & \\
\hline - rarely & $17.6 \%$ & $82.4 \%$ & \\
\hline - never & $19.4 \%$ & $80.6 \%$ & \\
\hline Perceived influence of extreme meteorological conditions (e.g., heat waves) on health: & & & 0.0179 \\
\hline - a lot & $15.2 \%$ & $84.8 \%$ & \\
\hline - average & $15.4 \%$ & $84.6 \%$ & \\
\hline - not much & $18.0 \%$ & $82.0 \%$ & \\
\hline - not at all & $21.2 \%$ & $78.8 \%$ & \\
\hline \multicolumn{4}{|l|}{ Dwelling } \\
\hline Type of dwelling: & & & $<0.0001$ \\
\hline - house & $28.1 \%$ & $71.9 \%$ & \\
\hline - apartment & $2.6 \%$ & $97.4 \%$ & \\
\hline Perceived efficiency of the dwelling's insulation against moisture: & & & $<0.0001$ \\
\hline - very good & $25.2 \%$ & $74.8 \%$ & \\
\hline$\cdot \operatorname{good}$ & $18.9 \%$ & $81.1 \%$ & \\
\hline - average & $15.6 \%$ & $84.5 \%$ & \\
\hline
\end{tabular}


Table 4: Use of residential wood heating in southern Québec for various respondents characteristics: percentages corrected for stratified sampling and $p$ value (Continued)

\begin{tabular}{|c|c|c|c|}
\hline poor & $7.3 \%$ & $92.7 \%$ & \\
\hline Perceived efficiency of the dwelling's insulation against cold: & & & $<0.0001$ \\
\hline - very good & $24.5 \%$ & $75.6 \%$ & \\
\hline - good & $20.4 \%$ & $79.6 \%$ & \\
\hline - average & $12.8 \%$ & $87.2 \%$ & \\
\hline - poor & $6.3 \%$ & $93.8 \%$ & \\
\hline Perceived efficiency of the dwelling's insulation against heat: & & & $<0.0001$ \\
\hline • very good & $27.1 \%$ & $72.9 \%$ & \\
\hline$\cdot$ good & $19.9 \%$ & $80.2 \%$ & \\
\hline average & $13.6 \%$ & $86.4 \%$ & \\
\hline - poor & $3.7 \%$ & $96.3 \%$ & \\
\hline Addition of insulating materials since the dwelling was built: & & & $<0.0001$ \\
\hline - yes & $26.6 \%$ & $73.4 \%$ & \\
\hline • no & $18.1 \%$ & $81.9 \%$ & \\
\hline - don't know & $6.4 \%$ & $93.6 \%$ & \\
\hline Replacement of doors or windows since the dwelling was built: & & & 0.3479 \\
\hline - yes & $20.5 \%$ & $79.5 \%$ & \\
\hline • no & $18.9 \%$ & $81.1 \%$ & \\
\hline Dwelling built before $1983^{3}$ : & & & 0.1684 \\
\hline - yes & $18.7 \%$ & $81.3 \%$ & \\
\hline • no & $21.5 \%$ & $78.5 \%$ & \\
\hline - unknown ${ }^{4}$ & $17.4 \%$ & $82.6 \%$ & \\
\hline \multicolumn{4}{|l|}{ Region of residence } \\
\hline Region lived in: & & & $<0.0001$ \\
\hline - Eastern Québec & $35.0 \%$ & $65.0 \%$ & \\
\hline - Northern part of southern Québec & $34.8 \%$ & $65.2 \%$ & \\
\hline - Central Québec & $30.7 \%$ & $69.3 \%$ & \\
\hline - Québec City region & $23.0 \%$ & $77.0 \%$ & \\
\hline - North of Montréal & $24.9 \%$ & $75.2 \%$ & \\
\hline - South of Montréal & $21.9 \%$ & $78.1 \%$ & \\
\hline - Montréal and Laval & $4.0 \%$ & $96.0 \%$ & \\
\hline Region of residence perceived as conducive to ice storms & & & 0.0828 \\
\hline - a lot & $15.2 \%$ & $84.8 \%$ & \\
\hline - average & $19.6 \%$ & $80.4 \%$ & \\
\hline - not much & $20.1 \%$ & $79.9 \%$ & \\
\hline - not at all & $22.8 \%$ & $77.2 \%$ & \\
\hline Region of residence perceived as conducive to winter smog & & & 0.0002 \\
\hline - a lot & $11.6 \%$ & $88.4 \%$ & \\
\hline - average & $15.8 \%$ & $84.2 \%$ & \\
\hline - not much & $20.2 \%$ & $79.8 \%$ & \\
\hline - not at all & $23.3 \%$ & $76.7 \%$ & \\
\hline Region of residence perceived as conducive to cold waves & & & 0.0003 \\
\hline - a lot & $14.0 \%$ & $86.0 \%$ & \\
\hline - average & $21.8 \%$ & $78.2 \%$ & \\
\hline - not much & $24.3 \%$ & $75.7 \%$ & \\
\hline - not at all & $23.6 \%$ & $76.4 \%$ & \\
\hline \multicolumn{4}{|l|}{ Transport } \\
\hline Frequency of use of an automobile: & & & $<0.0001$ \\
\hline - daily & $21.9 \%$ & $78.1 \%$ & \\
\hline - occasionally & $21.5 \%$ & $78.5 \%$ & \\
\hline - never & $6.8 \%$ & $93.2 \%$ & \\
\hline Use of a remote starter in winter & & & 0.2007 \\
\hline - yes & $23.4 \%$ & $76.6 \%$ & \\
\hline • no & $20.8 \%$ & $66.1 \%$ & \\
\hline \multicolumn{4}{|l|}{ Consultation of meteorological information in the media } \\
\hline - Temperature: & & & 0.2666 \\
\hline • always & $20.2 \%$ & $79.8 \%$ & \\
\hline - often & $19.2 \%$ & $80.8 \%$ & \\
\hline - sometimes & $19.5 \%$ & $80.5 \%$ & \\
\hline - rarely & $17.7 \%$ & $82.3 \%$ & \\
\hline - never & $12.5 \%$ & $87.5 \%$ & \\
\hline Smog warning: & & & 0.1205 \\
\hline
\end{tabular}


Table 4: Use of residential wood heating in southern Québec for various respondents characteristics: percentages corrected for stratified sampling and $p$ value (Continued)

\begin{tabular}{|c|c|c|c|}
\hline - always & $17.3 \%$ & $82.7 \%$ & \\
\hline - often & $16.4 \%$ & $83.6 \%$ & \\
\hline - sometimes & $19.2 \%$ & $80.8 \%$ & \\
\hline - rarely & $23.3 \%$ & $76.7 \%$ & \\
\hline • never & $20.1 \%$ & $79.9 \%$ & \\
\hline Intense cold warning: & & & 0.0594 \\
\hline • always & $19.8 \%$ & $80.2 \%$ & \\
\hline - often & $19.9 \%$ & $80.1 \%$ & \\
\hline - sometimes & $21.9 \%$ & $78.1 \%$ & \\
\hline - rarely & $15.4 \%$ & $84.6 \%$ & \\
\hline - never & $13.6 \%$ & $86.4 \%$ & \\
\hline Belief of the contribution of anthropogenic causes to climate change in the last fifty years: & & & 0.1904 \\
\hline - a lot & $19.4 \%$ & $80.6 \%$ & \\
\hline - average & $18.5 \%$ & $81.5 \%$ & \\
\hline - not much & $22.7 \%$ & $77.3 \%$ & \\
\hline - not at all & $15.6 \%$ & $84.4 \%$ & \\
\hline Prohibition of wood heating when there is winter smog: & & & $<0.0001$ \\
\hline - completely agree & $10.4 \%$ & $89.6 \%$ & \\
\hline - somewhat agree & $17.5 \%$ & $82.5 \%$ & \\
\hline - somewhat disagree & $24.2 \%$ & $75.8 \%$ & \\
\hline - completely disagree & $38.5 \%$ & $61.5 \%$ & \\
\hline
\end{tabular}

IWood heating was related to the independent variables using the Rao-Scott likelihood ratio chi-square test, which is a design-adjusted version of the Pearson chi-square test.

2The total percentages for a given variable may not be exactly $100 \%$, due to rounding to the closest decimal. To simplify the presentation, percentages below $2 \%$ for missing data have not been reported.

3 In 1983, the Law on Conservation of energy in buildings was adopted in Québec to insure a minimal performance of the thermal insulation in walls and ceilings.

${ }^{4} \mathrm{Among}$ these respondents ( $<5 \%$ of the participants), $73,3 \%$ lived in apartments.

tion and at least 4 for the respondents completely disagreeing.

\section{Discussion}

This population survey on beliefs and adaptations about climate change, including residential wood heating, did not intend to measure the impact of wood burning on the levels of air pollutants, nor the impact of related home indoor pollutants on the health of its inhabitants. However, this survey found the prevalence of residential wood heating to be $18.5 \%$ in Quebec (11.9\%, every day), which is very close to the approximately $20 \%$ documented by the 2003 Canadian Survey of Household Energy Use [28]. As well, heating with wood during the winter was not influenced by smog warnings. From a public health standpoint, these results are of concern for several reasons.

First, wood smoke associated with residential wood burning has known negative impacts on health. It is likely to cause a variety of adverse respiratory health effects, including increases in respiratory symptoms, lung function deterioration, and increased visits to emergency departments and hospitalizations [29]. Furthermore, wood smoke is an important contributor to particle concentrations [29] and its increased use could result in a substantial increase in the number of premature deaths [30]. Clearly, there seems to be no reason to assume that the effects of particulate matter in areas polluted by wood smoke are weaker than elsewhere [31].

Second, in 2003, 30\% of the atmospheric emissions generated by the total of fixed sources in Québec were attributable to wood heating and are increasing [32]. It is likely that residential biomass combustion will become even more widespread, given the recent upward trend in the costs of oil and natural gas [29]. Moreover, the use of wood as a primary or secondary source of heat is presently encouraged by the Canadian government as a useful adaptation in defense against the harmful effects of prolonged power outages brought on by extreme climatic events[9]. Furthermore, a close and continuous monitoring of the evolution in residential wood heating does not exist at the present time.

Third, even in densely populated urban environments where most people live in apartments and where the prevalence of wood heating is very low (e.g. Montréal in this survey), air quality can be severely affected by wood smoke. For example, air quality measures implemented between 1999 and 2002 in Montréal have demonstrated that some atmospheric pollutants (e.g. particulate matter) in a residential district using wood heating to a great extent were up to five times higher in winter than in sum- 
Table 5: Indicators differentiating occasional or daily users of residential wood heating from non-users: multivariate analysis corrected for stratified sampling

\begin{tabular}{|c|c|c|c|c|c|}
\hline Variables & OR' & $\mathrm{Cl}_{95 \%} \mathrm{I}$ & $P$ value ${ }^{2}$ & c index ${ }^{3}$ & Rank \\
\hline Modell & & & & 0.8176 & $1^{4}$ \\
\hline \multicolumn{6}{|l|}{ Sociodemographic characteristics } \\
\hline Income before tax, from all sources (last 12 months): & & & 0.0056 & & \\
\hline - $<\$ 45,000$ & \multicolumn{2}{|c|}{ reference group } & & & \\
\hline$\cdot \geq \$ 45,000$ & 1.1 & $0.9 ; 1.5$ & & & \\
\hline - not disclosed & 0.6 & $0.4 ; 0.9$ & & & \\
\hline First language learned at home: & & & 0.0257 & & \\
\hline - French only & \multicolumn{2}{|c|}{ reference group } & & & \\
\hline • English only & 0.3 & $0.1 ; 0.7$ & & & \\
\hline - other language in addition to French or English & 1.0 & $0.4 ; 2.8$ & & & \\
\hline - languages other than French and English & 0.6 & $0.3 ; 1.6$ & & & \\
\hline \multicolumn{6}{|l|}{ Dwelling } \\
\hline Type of dwelling: & & & $<0.0001$ & & \\
\hline - apartment & \multicolumn{2}{|c|}{ reference group } & & & \\
\hline - house & 10.8 & $6.7 ; 17.4$ & & & \\
\hline Perceived efficiency of the dwelling's insulation against heat: & & & 0.0009 & & \\
\hline - very good & \multicolumn{2}{|c|}{ reference group } & & & \\
\hline$\cdot$ good & 0.7 & $0.5 ; 0.9$ & & & \\
\hline - average & 0,6 & 0,$4 ; 0.8$ & & & \\
\hline - poor & 0.3 & $0.1 ; 0.6$ & & & \\
\hline Dwelling built before 1983 ': & & & 0.0159 & & \\
\hline - yes & \multicolumn{2}{|c|}{ reference group } & & & \\
\hline - no & 3.1 & $1.4 ; 6.7$ & & & \\
\hline - unknown & 1.0 & $0.8 ; 1.3$ & & & \\
\hline \multicolumn{6}{|l|}{ Region of residence } \\
\hline Region lived in: & & & $<0.0001$ & & \\
\hline - Eastern Québec & \multicolumn{2}{|c|}{ reference group } & & & \\
\hline - Northern part of southern Québec & 1.2 & $0.7 ; 2.1$ & & & \\
\hline - Central Québec & 1.0 & $0.6 ; 1.7$ & & & \\
\hline - Québec City region & 0.7 & $0.4 ; 1.1$ & & & \\
\hline - North of Montréal & 0.7 & $0.5 ; 1.1$ & & & \\
\hline - South of Montréal & 0.7 & $0.5 ; 1.1$ & & & \\
\hline - Montréal and Laval & 0.2 & $0.1 ; 0.4$ & & & \\
\hline Consultation of smog warning in the media & & & 0.0112 & & \\
\hline - always & \multicolumn{2}{|c|}{ reference group } & & & \\
\hline - often & 0.9 & $0.6 ; 1.4$ & & & \\
\hline - sometimes & 1.2 & $0.8 ; 1.7$ & & & \\
\hline - rarely & 1.4 & $0.9 ; 2.1$ & & & \\
\hline - never & 0.8 & $0.5 ; 1.1$ & & & \\
\hline \multicolumn{6}{|l|}{ Beliefs } \\
\hline Belief of the contribution of anthropogenic causes to climate change in the last fifty years: & & & 0.0388 & & \\
\hline - a lot & \multicolumn{2}{|c|}{ reference group } & & & \\
\hline - average & 0.8 & $0.6 ; 1.1$ & & & \\
\hline - not much & 1.0 & $0.7 ; 1.5$ & & & \\
\hline - not at all & 0.5 & $0.3 ; 0.9$ & & & \\
\hline Prohibition of wood heating when there is winter smog: & & & $<0.0001$ & & \\
\hline - completely agree & \multicolumn{2}{|c|}{ reference group } & & & \\
\hline - somewhat agree & 1.8 & $1.3 ; 2.6$ & & & \\
\hline - somewhat disagree & 2.6 & $1.9 ; 3.6$ & & & \\
\hline - completely disagree & 5.2 & $3.6 ; 7.5$ & & & \\
\hline Model2 & & & & 0.8029 & $64^{5}$ \\
\hline Type of dwelling: & & & $<0.0001$ & & \\
\hline - apartment & \multicolumn{2}{|c|}{ reference group } & & & \\
\hline - house & 10.0 & $6.2 ; 16.2$ & & & \\
\hline Region lived in: & \multirow{2}{*}{\multicolumn{2}{|c|}{ reference group }} & $<0.0001$ & & \\
\hline - Eastern Québec & & & & & \\
\hline - Northern part of southern Québec & 1.1 & $0.7 ; 1.9$ & & & \\
\hline
\end{tabular}


Table 5: Indicators differentiating occasional or daily users of residential wood heating from non-users: multivariate analysis corrected for stratified sampling (Continued)

\begin{tabular}{lll}
\hline - Central Québec & 1.0 & $0.6 ; 1.7$ \\
- Québec City region & 0.7 & $0.4 ; 1.1$ \\
- North of Montréal & 0.7 & $0.4 ; 1.0$ \\
- South of Montréal & 0.7 & $0.4 ; 1.0$ \\
- Montréal and Laval & 0.2 & $0.1 ; 0.3$ \\
Prohibition of wood heating when there is winter smog: & & $<0.0001$ \\
- completely agree & & reference group \\
- somewhat agree & $1.8 \quad 1.3 ; 2.6$ \\
- somewhat disagree & $2.5 \quad 1.8 ; 3.4$ \\
- completely disagree & 4.4 & $3.1 ; 6.2$
\end{tabular}

IOR: odds ratio; IC $95 \%$ : $95 \%$ confidence interval

${ }^{2} \mathrm{p}$ value associated with the Wald test by means of logistic regression.

${ }^{3}$ Area under the ROC curve; between 0.8 and 0.9 : good model. No collinearity between the independent variables was observed.

464 models had a $\mathrm{c}$ index over 0.8 . This model ranked first.

564 models had a c index over 0.8 . This model ranked last.

mer, and up to two times higher in winter in that district than in downtown high traffic areas [33].

Fourthly, this survey found that the use of residential wood heating does not seem to be influenced either by the perception of living in a region conducive to smog, or by the smog warnings emitted by Environment Canada through the media. This may be due to the fact that the Info-Smog program did not cover the regions with the highest prevalence of wood heating during this study. This program informs the population through the media about the presence of meteorological conditions conducive to increased atmospheric pollution, and sends, at the same time, advice about reducing the sources of pollution and their health impacts [34]. This is a possible but refutable hypothesis: the perception and warnings about smog do not seem to affect the use of an automobile or a remote starter (two other sources of smog) in Montréal [17], where Info-Smog has existed since its creation in 1994 [34]. However, many other determinants - besides the perception of risk and the knowledge relating to it - can promote the adoption of a health-related behaviour, and these are mainly habit, social determinants (e.g., behaviour standards, pressure felt), beliefs, moral principles $[35,36]$, and other variables (e.g. type of dwelling, accessibility of wood) in particular in regions characterized by colder and longer winters [37].

Finally, the average age of wood stoves used as the primary heating system in Canada was 12 years in 2003 [38] and it is likely that the stoves used as a secondary source of heat are just as old. Chances are that a significant proportion of these appliances are not certified according to the standards of the United States Environmental Protection Agency (EPA) [39] or not approved by the Canadian Standards Association (environmental performance standard B.415.1-04), if only because the costs of purchasing and installing the new technologies would be between $\$ 1,800$ and $\$ 5,000$ per stove [40]. In addition, no Cana- dian law prohibits the sale of uncertified wood burning appliances, which emit in nine hours as much fine particulate matter into the atmosphere as a certified stove operating for 60 hours, or as an intermediate type automobile traveling $18000 \mathrm{~km}$ in a year [7]. In this survey, the type of appliance and the year of acquisition were not evaluated. However, it would be surprising that these specifications differ greatly from the rest of Canada.

Consequently, in Canada and other similar cold regions (e.g. Northern Europe, Russia), it would be appropriate to implement long-term national programs on residential wood heating to reduce pollutant emissions at source. Such a program could simultaneously include feasible adaptation measures of the "no-regrets" type (which are measures with climatic and non-climatic benefits). Such an approach would include educational measures (e.g. observance of good practice), incentive measures (e.g. financial assistance for replacing a conventional appliance and its recycling), and legislative measures including various control strategies (e.g. prohibition of the sale of uncertified wood burning appliances, prohibition of wood heating on smog days) $[40,41]$ plus simultaneous mechanisms to ensure their application (e.g., high fines for polluting citizens and municipal administrations). In addition, close and continuous monitoring [42] of the evolution in residential wood heating would be necessary, including variables related to atmospheric and indoor pollutants, appliances, their actual use, installation and maintenance, users, the natural environment (e.g., wind, topographical characteristics) and the dwellings (e.g., ventilation of the dwelling). Finally, research is needed on the cultural and psychosocial determinants of heating practices to help focus intervention programs and on the health impacts of wood heating for highly exposed groups under conditions of a developed country [30], as is the case for Québec. 


\section{Conclusion}

In recent years, much has been written about heat waves that have occurred in some industrialized countries. While this is important, it would be also desirable to remember that there will still be winters and periods of intense cold in the northern regions, such as Canada, and that people will still have to continue to adapt to them. It is indisputable that wood heating is an interesting adaptation strategy for protection against the cold during extreme climatic events that can lead to prolonged power outages, particularly when this renewable energy resource is easily accessible in several northern countries. However, in the light of the results of this study and the literature on air pollution and climate change, it is important to state that much remains to be done, individually and collectively, to avoid wood heating becoming in fact a maladaptation. In light of the precautionary principle, the current imprecise and incomplete "scientific evidence" associated to the health and environmental impacts of residential wood heating is, in our view, an additional reason to implement a long-term national program on improved and controlled wood heating as part of "no-regrets" adaptation measures to climate change that brings more heating autonomy to dwellings during severe climate events while reducing air pollution and its associated health impacts.

\section{Competing interests}

The authors declare that they have no competing interests.

\section{Authors' contributions}

DB lead the conception, design, analysis and interpretation of the study. DB and PG wrote the paper. PG, PV and $\mathrm{BA}$ reviewed the paper and were involved in the design of questionnaire and sampling. All gave their final approval of this version.

\section{Acknowledgements}

This study was made possible by the financial support of the Ministère de la Santé et des Services sociaux du Québec, Health Canada's Climate change and Health office, and the Ouranos Consortium, by the professionalism of the Léger Marketing polling firm, and the invaluable collaboration of many Quebecers. G. Martineau reviewed the bibliography and S. Owens made many useful suggestions. To all, thank you.

\section{References}

I. Warren FJ, Barrow E, Schawrtz R, Andrey J, Mills B, Riedel D: Climate Change Impacts and Adaptation: A Canadian Perspective. 2004 [http://adaptation.nrcan.gc.ca/perspective/index e.php]. Ottawa: Government of Canada Retrieved in October 2007

2. Yagouti A, Boulet G, Vescovi L: Évolution des températures au Québec méridional entre 1960 et 2003. 2003 [http:// www.mddep.gouv.qc.ca/chang-clim/meridional/resume.htm]. Québec: Ministère du Développement durable, de l'Environnement et des Parcs Retrieved in October 2007

3. MacCracken M, Barron E, Easterling D, Felzer B, Karl T: Scenarios for climate variability and change. Climate change impacts on the United States: the potential consequences of climate variability and change. Cambridge: Cambridge University Press; 2001.
4. Beaudreau P, Besancenot JP, Caserio-Schönemann C, Cohen JC, Dejour-Salamanca $D$, Empereur-Bissonnet $P$, et al.: Froid et santé: éléments de synthèse bibliographique et perspectives. 2004 [http://www.invs.sante.fr/publications/2004/froid et sante/ rapport froid et sante.pdf]. Saint-Maurice: Institut de veille sanitaire Retrieved in October 2007

5. Doyon B, Bélanger D, Gosselin P: Effets du climat sur la mortalité au Québec méridional de $198 \mathrm{I}$ à 1999 et simulations pour des scénarios climatiques futurs. 2007 [http://www.inspq.qc.cal pdf/publications/536-EffetsCimatMortalite Quebec.pdf]. Québec: Institut national de santé publique du Québec Retrieved in October 2007

6. Environment Canada: Residential Wood Heating [http:// www.ec.gc.ca/cleanair-airpur/default.asp?lang=En\&n=50E7D 55 I-I]. Retrieved in October 2007

7. Ministère du Développement durable, de l'Environnement et des Parcs: Le chauffage au bois [https:// www.mddep.gouv.qc.ca/air/chauf-bois/index.htm]. Retrieved in October 2007

8. Office of Critical Infrastructure Protection and Emergency Preparedness Disaster database Climate Change Impacts and Adaptation: A Canadian Perspective 2004 [http://adaptation.nrcan.gc.cal perspective/index e.php]. Ottawa: Government of Canada Retrieved in October 2007

9. Natural Resources Canada: Renewable Energy in Action [http://www.canren.gc.ca/renew ene/ index.asp?Cald=47\&Pgld=| | 38]. Retrieved in October 2007

10. Environment Canada, Statistics Canada and Health Canada: Canadian Environmental Sustainability Indicators 2006 [http://www.statcan.ca/english/freepub/|6-25|-X|E/|6-25|XIE2006000.pdf]. Retrieved in October 2007

II. Environment Canada: Wood Heating Facts [http:// www.ec.gc.ca/cleanair-airpur/default.asp?lang $=E n \& n=87 C 5 E E 65-I]$ ] Retrieved in October 2007

12. Ministère du Développement durable, Environnement et Parcs: Wood Heating [http://www.mddep.gouv.qc.ca/air/chaufbois/index.htm]. Retrieved May 15, 2006

13. Environment Canada: About the Air Quality Index [http:// www.ec.gc.ca/cas-aqhi/default.asp?lang $=$ En\&n=065BE995-I]. Retrieved on December 10, 2007

14. Lévesque B, Auger PL, Bourbeau J, Duchesne JF, Lajoie P, Menzies D: Qualité de l'air intérieur. In Environnement et santé publique: fondements et pratiques Volume Chapitre 12. Paris: Éditions Tec \& Doc; 2003. 1023 pages

15. Auger PL, Verger P, Dab W, Guerrier P, Lachance A, Lajoie P, Leroux $R$, Rhainds M, Roy LA: Sinistres naturels et accidents technologiques. In Environnement et santé publique: fondements et pratiques Volume Chapitre 20. Paris: Éditions Tec \& Doc; 2003. 1023 pages

16. Willey J, Gilbert N, Lyrette N: Human Health Effects of Ozone: Update in Support of the Canada-wide Standards for Particulate Matter and Ozone, revised version. Working paper prepared for the Canadian Council of Ministers of the Environment 2004 [http://www.statcan.ca/english/freepub/I6-25I-XIE/I6-25IXIE2006000.pdf]. Ottawa, Ontario: Health Canada Cited in Environment Canada, Statistics Canada and Health Canada: Canadian Environmental Sustainability Indicators. Retrieved in October 2007

17. Bélanger D, Gosselin P, Valois P, Abdous B: Vagues de froid au Québec méridional: adaptations actuelles et suggestions d'adaptations futures. 2006 [http://www.inspq.qc.ca/pdf/publica tions/537-VaguesFroid Quebec.pdf]. Québec: Institut national de santé publique du Québec Retrieved in October 2007

18. Alavi A, Beaumont JF: Evaluation and adjustment for nonresponse in the Canadian Labour Force Survey. [http:// www.statcan.ca/bsolc/english/bsolc?catno=||-522-X200300|7598]. Retrieved in October 2007

19. Institut de la statistique du Québec: Recensement de la population 200I [http://www.stat.gouv.qc.ca/regions/lequebec/ quebec index.htm\#population]. Retrieved in October 2007

20. Thompson SK: Sample size for estimating multinomial proportions. The American Statistician 1987, 4 I(I):42-46.

21. Bélanger D, Gosselin P, Valois P, Abdous B: Vagues de chaleur au Québec méridional: adaptations actuelles et suggestions d'adaptations futures. 2006 [http://www.inspq.qc.ca/pdf/publica tions/538-VaguesChaleur Quebec.pdf]. Québec: Institut national de santé publique du Québec Retrieved in October 2007 
22. Presser S, Rothgeb JM, Couper MP, Lessler JT, Martin E, Martin J, Singer $E$ : Methods for testing and evaluating survey questionnaires. Hoboken (NJ): John Wiley \& Sons; 2004.

23. Statistique Canada: Enquête sociale et de santé 1998 [http:/ /www.stat.gouv.qc.ca/publications/sante/pdf/e soc98v2-2.pdf]. Retrieved in October 2007

24. Sautory O: Atelier sur les procédures SAS d'échantillonnage et d'analyse de données d'enquête. In Colloque francophone sur les sondages Québec: Université Laval; 2005.

25. R Development Core Team: R: A language and environment for statistical computing. [http://www.R-project.org]. R Foundation for Statistical Computing, Vienna, Austria ISBN 3-90005I-07-0, Retrieved in October 2007

26. Hosmer DW, Lemeshow S: Applied logistic regression. New York, NY: John Wiley \& Sons; 1989.

27. Kleinbaum DG, Kupper LL, Muller KE: Applied regression analysis and other multivariate methods. Boston, MA: PWS-KENT; 1988.

28. Natural Resources Canada: 2003 Survey of Household Energy Use [http://oee.nrcan.gc.ca/corporate/statistics/neud/dpa/ data e/sheu03/tables.cfm?attr $=0$ ]. Retrieved in October 2007

29. Naeher LP, Brauer M, Lipsett M, Zelikoff JT, Simpson CD, Koenig JQ, Smith KR: Woodsmoke Health Effects: A Review. Inhalation Toxicology 2007, 19:67-106.

30. Ballester F, Medina S, Boldo E, Goodman P, Neuberger M, Iñiguez C, Künzli N, on behalf of the Apheis network: Reducing ambient levels of fine particulates could substantially improve health: a mortality impact assessment for 26 European cities.

31. Boman $B C$, Forsberg $A B$, Järvholm BG: Adverse Effects from Ambient Air Pollution in Relation to Residential Wood Combustion in Modern Society. Scand J Work Environ Health 2003, 29(4):25I-260.

32. Institut national de santé publique du Québec et ministère de la Santé et des Services sociaux du Québec en collaboration avec I'Institut de la statistique du Québec. Portrait de santé du Québec et de ses régions 2006: les analyses. Deuxième rapport national sur l'état de santé de la population du Québec. Gouvernement du Québec. . I3| pages

33. Ministère du Développement durable, Environnement et Parcs: Rapport sur le chauffage résidentiel au bois [http:// www.mddep.gouv.qc.ca/air/chauf99-02/index.htm]. Retrieved in October 2007

34. Environment Canada: Fact sheet: Winter Info-Smog Program [http://lavoieverte.qc.ec.gc.ca/atmos/dispersion/main e.html]. Retrieved in October 2007

35. Core Group: Behavioral determinants inter-working group meeting at the Academy for Educational Development. [http://www.coregroup.org/working groups/

Determinants meeting rpt0903.pdf]. Retrieved in October 2007

36. Fishbein M, Triandis HC, Kanfer FH, Becker M, Middlestadt SE, Eichler A: Factors influencing behavior and behavior change. In Handbook of health psychology Edited by: Fishbein M, Triandis HC, Kanfer FH, Becker M, Middlestadt SE, Eichler A. New Jersey: Laurence Earlbaum Associates; $200 \mathrm{I}$.

37. Racette B: Les bonnes pratiques du chauffage au bois... pour de l'air frais et des économies. [http://www.creat08.ca/pdf/ even coll/bois/bonnesPratiquesl.pdf]. Retrieved in October 2007

38. Natural Resources Canada: 2003 Survey of Household Energy Use (SHEU) - Summary Report [http:// www.oee.nrcan.gc.ca/publications/statistics/sheu-summary/ index.cfm?attr=0]. Retrieved in October 2007

39. U.S. Environmental Protection Agency: Wood stoves certification. [http://www.epa.gov/Compliance/monitoring/programs/caa/ whcert.html]. Retrieved in October 2007

40. Del Matto T, Foster D, Wolnik C, Kassirer J, Southam T, Poitras J: Feasibility assessment of a Change-out/Education Program for Residential Wood Combustion. [http://www.ccme.ca/ assets/pdf/rwc final report.pdf]. Retrieved in October 2007

41. Environment Canada: Model Municipal By-law for regulating woodburning appliances. [http://www.ec.gc.ca/cleanair-airpur/ default.asp?lang=En\&n=975A 1778-I]. Retrieved in October 2007

42. Kyle AD, Wright CC, Caldwell JC, Buffler PA, Woodruff TJ: Public Health Reports 200I, I 16:32-44.

\section{Pre-publication history}

The pre-publication history for this paper can be accessed here:

http://www.biomedcentral.com/1471-2458/8/184/pre pub
Publish with Bio Med Central and every scientist can read your work free of charge

"BioMed Central will be the most significant development for disseminating the results of biomedical research in our lifetime. "

Sir Paul Nurse, Cancer Research UK

Your research papers will be:

- available free of charge to the entire biomedical community

- peer reviewed and published immediately upon acceptance

- cited in PubMed and archived on PubMed Central

- yours - you keep the copyright

Submit your manuscript here:

http://www.biomedcentral.com/info/publishing_adv.asp
BiolMedcentral 